\title{
CREATING INNOVATIVE PRODUCT IN FINANCIAL ENGLISH
}

Elena Gavrilova, Kira Trostina, Plekhanov Russian University of Economics, helena0517@mail.ru, kiratrostina@mail.ru

\begin{abstract}
Most of authentic textbooks and other teaching material on Financial English for higher education deal with internationally generalized issues without covering national peculiarities. Such a gap in the educational literature market can be filled only with customized material, catered for the specific purposes, to train students in their particular area of specialization and to provide them with abundant autonomous workload. The article describes the experience of Russian-speaking ESP teachers who approach creating an innovative e-training educational program in English of Finance and Accounting as a business project. A complex research to analyze university and students' needs and teachers' expectations is carried out. To estimate the input versus prospective output SWOT analysis for the project is conducted. Outlined in the article are the challenges the project faces, and some ways of solving such problems as copyright, IT or workgroup support and others are suggested. Features of an innovative educational product for Financial English are identified.
\end{abstract}

UDC Numbers: 81`24, DOI: 10.12955/cbup.2013.29

Keywords: higher education, innovation, Financial English

\section{Introduction}

A diversified higher education program portfolio for master's degree in economics suggests training students in the field of their specialization by enhancing their autonomous research work via expanded assignments where the knowledge of a foreign language is viewed as a means of getting new professional information. Nevertheless, recent changes in university curriculum have reduced the number of interactive teacher-student hours, which affects the traditional pattern of language practice received by students. The existing teaching material for Financial English can be used for self-study, while training communication skills is hardly possible without attending a group lesson. Applying elearning methods to simulate classroom activities could partially solve the problem of the insufficient number of traditional seminars. Amongst the available e-learning products for English for Specific or Professional Purposes, 'Cambridge Financial English Blended Learning Course' definitely stands out for its variety of tasks and professionally oriented approach, being a benchmark for those who would like to create a similar program for the needs of their students. The international best practice in Finance and Accounting is worth studying while mastering English at undergraduate level, whereas national models and standards have to be examined as well. Surveying our students' requirements for the ESP e-course we judge that a customized program should be developed for their specific or local area of finance. Along with being interactive to train a variety of skills to make up for the shortage of 
face-to-face classes and to generate further interest in studies, such a program would also highlight the recognized methods of providing financial services nationwide.

Creating a truly innovative product to teach English for Specific or Professional Purposes is a complicated process involving many aspects. University teachers aspiring to draw up their own original program in Financial English have to face a few challenges. We are going to conduct different kinds of analyses, consider all advantages and disadvantages, and evaluate the process of creating our own innovative e-product in teaching English for Finance and Accounting.

\section{Stimulating independent learning}

All reforms taking place in society are always associated with reforms and innovations in education. Modern Russia is aspiring to integrate into European educational area and develop close links with other countries, which was confirmed by signing the Bologna declaration in September 2003. Right now Russia is in the final stage of aligning its educational activities with international ones. This reorganization involves hard work on upgrading educational programs, teaching methods and techniques in accordance with the new demands. Performing these tasks scholars and academics in Russia are facing some new challenges.

To begin with, the world educational community considers further complication of curricula and an increase of academic hours to be inefficient. The majority of European universities are decreasing the number of traditional introductory lectures and practical seminars along with increasing the time for students' self-study and research. The focus of education is on students' autonomous search for knowledge under the supervision of competent teachers. However, this has never been the case with the Russian system of education, which historically prided itself on large amounts of profound theoretical knowledge given at numerous lectures and seminars. Teachers in Russia have always done their best to pump as much information as possible into students' heads during their classroom time, and one could often hear them complaining to each other: "I had three more interesting exercises to do, but the lesson was already over". Definitely, nobody can blame them for their enthusiasm and desire to give more knowledge to their students, but today's reality urgently requires searching for new methods of teaching. Presently, classes are more and more arranged in the form of individual and group consultations, workshops, brainstorming sessions and virtual communication. The current situation prompts all university lecturers and ESP teachers in particular to seek new forms and devise new ways to train their students in new conditions. The role of the modern university language teacher more and more shifts from traditional information-providing towards instructing and facilitating students' autonomous search for knowledge. The idea is to raise students' interest, creativity and personal responsibility for the quality of education they get.

This task puts forward new requirements for teaching material. Modern education has to be blended, i.e. combining face-to-face classroom methods with computer-mediated activities. According to its proponents, such a strategy creates a more integrated approach for both instructors and students. Therefore, print, once the primary method of instructional delivery, is now increasingly being replaced with innovative interactive educational products which offer unlimited opportunities for a researchbased, practical integration of new technology and traditional methods. Moreover, approaches to creating e-learning innovative materials have advanced greatly over the last two decades due to putting emphasis on the role of learners during the training process, aiming to enhance the development of independent thinking and facilitate all necessary skills for their future business communication and 
professional activities. And last but not least, such resources should also enable students to broaden their language repertoire, stimulate cognitive effort and get immediate feedback.

\section{Financial English teaching in Russia today}

Each educational institution tackles these issues in their own way struggling to offer their students unique educational programs and materials. For example, being one of the oldest and most progressive economic universities in Russia Plekhanov Russian University of Economics (PRUE) has always prided itself on providing high-quality educational services tailored according to the demands of the quickly changing world. Every year the university introduces new courses, which become more and more narrowly specialized, as modern employers expect applicants not to be specialists in finance in general but to demonstrate profound knowledge and working skills in specific areas such as insurance, corporate finance or tax administration, etc. Thus, future graduates are well aware that their prospective employability depends to a great extent on the quality of their education.

The insight into Financial English learning shows that today's both Bachelor and Master undergraduates are much more demanding and put more pressure on the teaching staff than ever before. All university lecturers are encouraged to create their own courses to satisfy the increasing demands of students. Though this task is not easy for any university lecturer or professor, ESP teachers unexpectedly have to sort out some additional problems. Firstly, in contrast to the abundance of courses on General and Business English, books and teaching material for professional purposes are relatively scarce. Secondly, there is divergence in methods of delivering financial and accounting data in authentic textbooks and corresponding topics in countries outside Europe and North America, for instance, Russian textbooks, and ESP teachers have to find the ways to complement them. For example, the methods of teaching accountancy in Russia differ greatly from those in continental Europe, the UK and the USA. As none of the textbooks created by native-speaking authors highlights this fact, Russian teachers of English for Accounting always have to devise various ways to train their students to compare and analyze the differences and similarities in domestic and foreign practices of accounting, as well as to keep up with the changes constantly emerging in these spheres.

Still more important is the fact that in the last decades the Russian government has been implementing a program to harmonize its national accounting standards with the International Financial Reporting Standards (IFRS), which correspondingly needs to be reflected in the classroom. The same applies to many other countries with similar problems where at present only customized innovative teaching material for both home and foreign contents can perform the task to bridge the standards gap and to devise a relevant glossary. So ESP teachers always face the dilemma whether to teach their students internationally generalized issues or develop their own innovative teaching materials to cover these topics as they are taught in Russia. Finally, as none of the curricula takes these matters into account, it very often happens that we teach students their professional topics in English first, and only some time later they study the same subject in Russian, which often causes some confusion.

\section{Emphasis on professional purposes}

Undergraduate students of the Finance Faculty of the Plekhanov Russian University of Economics study a foreign language for specific and professional purposes (the ESPP - English for Special and Professional Purposes) in the areas of Financial Management, Banking, Securities, Taxation and Insurance; of the Faculty of Business, in the areas of Accounting and Audit; and of the Department of 
Distance Learning, all university ESPP programs. In order to elicit the problems of an ESPP course and consider advantages and disadvantages of creating our own innovative product in Financial English, we have conducted research in which we analyzed:

- authentic textbooks on Finance, Accountancy, Insurance, Banking, Taxation, etc.,

- Russian textbooks on the same subjects,

- free e-learning materials,

- original articles from FT, the Economist, New York Times, etc.,

- opinions and recommendations of our immediate colleagues (more than 20),

- statistical data from the survey of students' opinions about the ESP course.

The first priority in teaching ESPP is to study the professional jargon in depth, to develop the ability to work with a specially created glossary, and, finally, to trigger including the memorized words and expressions into the active vocabulary through exercises and extensive reading of authentic English texts in the given field. Mastering the content of the basic textbooks of senior courses during the ESPP course of the Finance Faculty, i.e. "Professional English in Use: Finance" by Ian MacKenzie and "Accounting and Finance" by Sara Helm, together with learning a lot of professional terms, doing exercises on vocabulary reinforcement and working with excerpts from authentic texts successfully solves the aforesaid problem. These textbooks were written by leading specialists of the best US and UK universities for foreign learners of English, have been tested in various educational establishments all around the world and won acclaim of both teachers and students.

Each of these Professional English textbooks has their own block of specific terms, concepts and definitions for active learning which are necessary for the future specialist for further communication and professional development. Implementation of the task of training large amounts of active and passive vocabulary is very complex, since, in line with the recent pan-European trends in higher education, the number of classroom practice or interactive hours for ESPP is too small, while the time for self-study and autonomous research work has been increased. Such a massive task is feasible only through the implementation of several required conditions, namely:

- a well-designed, consistent and coherent program of language training for special and professional purposes;

- a variety of modern blended learning techniques, used to organize extracurricular and classroom activities for students;

- innovative methods letting teachers maximally enhance the learning process.

Undoubtedly, foreign English language teachers are not supposed to duplicate already existing numerous authentic textbooks and teaching materials, but they are expected to provide the proper ways of teaching students of their own nationality. Creating tailor-made and personalized teaching materials is an effective means of enhancing the learning process at the local level. Traditionally, in order to improve their ESP courses teachers embrace empirical data collected from their own teaching experience and extensive reading, as well as exchanging their ideas with colleagues from their department and counterparts from partner universities and business schools and consulting university professors from other departments teaching these subjects in Russian. Unfortunately, it should be noted that seeing the scope of the task, not being equipped with the right methodology or feeling the lack of support from the university authorities some teachers become discouraged and unwilling to develop innovative courses. Additionally, many teachers have found themselves psychologically unprepared for their new professional routine and outstretched boundaries of their activity and urgently need a roadmap to show them the way. 
Prior to developing an innovative ESPP course it was also necessary to understand the students' needs. A questionnaire was distributed among 271 undergraduates of 'Finance and Credit' sub-faculty and 58 undergraduates of 'Taxes and Taxation' sub-faculty of the Faculty of Finance; 46 undergraduates of 'Accounting and Audit' of the Faculty of Business; and those 97 students, who were studying Professional English as a compulsory discipline while doing their Master's degree at the Faculty of Finance and the Faculty of Distance Learning in 2011-2012. We offered them to answer three questions:

1. How do you feel about the course you have completed?

a) very satisfied;

b) satisfied but would like it to be more specific in my specialization;

c) dissatisfied.

The majority of respondents $(71 \%)$ noted that they were satisfied with the course but would like it to be more specific according to their specialization, $27 \%$ were very satisfied and only $2 \%$ felt that the course didn't match their expectations.

2. What would you like to see more emphasis on?

Answering the open question the students mentioned speaking and case analysis, international professional examination preparation, professional listening, professional writing, professional vocabulary, etc. Unsurprisingly, none of the respondents remembered grammar, but about $73 \%$ claimed that they wanted more training in the specific vocabulary of their particular specialization, such as 'Securities and Derivatives', 'Equity Management', 'Strategic Finance' or 'Evaluation of Expert Reports'. Few students (5\%) highlighted the necessity of training professional writing skills, but rather many wanted to receive more training to take an international certificate examination such as BEC Higher or ICFE.

3. Where would you like to work after graduating from PRUE: a Russian company or a foreign company?

$37 \%$ of our undergraduates definitely want to seek employment with international companies, especially the Big Auditing Four where they are supposed to be tested on their professional language skills during the interview and where they will be able to apply their knowledge of Professional English. 28\% feel a bit uncertain about their language capabilities but would like to try joining a transnational company if they are given a chance, $12 \%$ have not decided yet where they are going to work. $23 \%$ want to work only in a Russian company.

Hence the majority of our graduates would like to use their professional English language skills, so the necessity of creating innovative learning material for ESPP is absolutely evident.

\section{Problems and prospects of e-product}

Approaching the task of creating an innovative e-product in Financial English we have realized that to produce a genuine learning material we need to set ourselves a clear objective that will help us devise and clearly structure the targeted product. In view of this, a SWOT analysis of the present education market for Financial English in Russia needed to be carried out. We have identified the following Strengths, Weaknesses, Opportunities and Threats for the project we are developing (Table 1). 
Table 1: Strengths, Weaknesses, Opportunities and Threats of the project

\begin{tabular}{|l|}
\hline Strengths \\
\hline - \\
brand name - we work in one of the oldest \\
economic universities in Russia (PRUE has \\
celebrated its $106^{\text {th }}$ anniversary); \\
- established customer base - we work at the \\
largest PRUE faculties: faculty of Finance, \\
faculty of Business and faculty of Distance \\
learning with over one thousand \\
undergraduate bachelors and MA course \\
students;
\end{tabular}

- the authors' proven professional reputation - we have more than 20 years' experience of teaching in business and financial English;

- practical approach - we know our students' needs and feel which gaps in the market should be filled;

- willingness - we are enthusiastic and creative.

\section{Opportunities}

- copyright permission - we can apply for written copyright permission on the ground of partner agreements between our university and the copyright holders;

- recent IT technologies - we can work in collaboration with outsourced IT specialists;

- over-the-university market - we can prepare a trial chapter and try to get the outside publishers interested in it;

- multinational customers - we can approach the educational market of the CIS, where many nations speak Russian as a second native language, thus exercises on translation can be in demand;

- automatically upgraded hyperlinks will solve the problem of data obsolescence;

- partner cooperation with a native speaker a specialist in finance and accounting, whose expertise will eliminate both linguistic or professional errors.
Weaknesses

- language - we are not native-speakers;

- economic qualifications - we do not have any formal or systematic education either in finance or in other related areas;

- time constraints - financial and accounting data very quickly become outdated while creating an e-textbook is very time-consuming;

- costs - it may be too expensive to produce such a product due to the relatively narrow target audience, since the diseconomies of scale have to be taken into account;

- limited programming opportunities - very few testing formats, mostly multiple choice, are supported by the IT department;

- insufficient support from university authorities.

\section{Threats}

- copyright lawsuits - we have to face the impossibility to use authentic materials without copyright infringement;

- competition - not only mainly from larger international educational publishers but from other domestic universities as well;

- obsolescence - the language is constantly evolving, and the studied professional regulations are being modified or updated.

Source: Authors

Therefore, while making an attempt to create an innovative product for the ESPP the first thing which a teacher of foreign languages - not a native English speaker and not a professional financier - has to face is competition with the best world-class experts in the field. The second difficulty to overcome is copyright, which is protected in all foreign publications, so even a partial use of certain phrases or sentences is not possible without the written permission of the author or publisher and may lead to litigation. Although in the public domain there are a few free text resources of the Internet, they still must be used with caution. Finally, due to the fact that during the process of designing a modern 
innovative product language teachers have to deal with most advanced computer software, they must not only be highly confident computer-users, but also possess at least minimal programming skills, as not all types of exercises can be transformed into electronic format using ready-made software.

It is obvious that an individual language teacher or a group of teachers aspiring to create their own high-quality innovative product, able to supplement or locally substitute the best foreign study materials, not only should possess high professionalism and motivation but vitally need full cooperation and support from their university. In particular, the written copyright permission of selected paragraphs or units, for example, of "Professional English in Use: Finance", can probably be obtained within the framework of partner cooperation between REU and Cambridge University Press. A similar agreement with leading foreign publishers could greatly facilitate the creation of an innovative product for the ESPP, as it will provide an opportunity to legally use the texts for which English teachers have already developed a system of additional tasks, exercises and computer tests. Complementing these texts and training system with references to professional on-line dictionaries and encyclopedias can provide a sound basis for the further development of innovative teaching material.

Moreover, it is essential to set up a system of motivation of teachers who work on such a product, using not only tangible financial incentives but also providing intangible benefits necessary for creation and creativity enhancement. One of the most important factors in working on such a project is the time that teachers have to find by reallocating priorities in their "work-life" balance. Forming a working group of teachers partially exempted from academic workload can accelerate the process of creating an innovative product and positively affect the quality of the course being developed.

At the last stage of preparation of e-learning materials foreign language teachers must combine their efforts with information technology specialists who will provide technical support in the interactive design of the product, namely:

- translating text documents into a structured format, in which the content is divided into levels and sub levels, and setting hyperlinks;

- adapting a system of exercises and tests for an interactive format, programming tooltips and automatic check of the tasks;

- uniting in the final product all the "stuffing" designed and conceived by teachers, specifically, PowerPoint and Prezi presentations, text documents, audio and video files.

It seems reasonable that to the greatest extent the innovative ESPP product will be in demand at the Faculty of Distance Learning, where the entire educational process is based on remote teaching methods, such as webinars, online tutorials, computer and online tests. The role of teacher in the education process is reduced to setting goals and objectives of training, on-line counseling and classroom control of knowledge. Obviously, the creation of the autonomous interactive product for distance learning, which will offer students a sufficient variety of self-sustaining tasks and will give undergraduates the opportunity not only to expand their vocabulary but also to improve cross-cultural communication skills and develop vocational competences, requires serious processing and reworking of the content of ESPP programs.

In the process of our research on existing traditional paper textbooks and available e-learning materials for Financial English teaching, taking into account our students' needs and having analyzed the prospective innovative product environment, we have come to the conclusion that to be successful in a nearly saturated market an innovative educational product should be:

- distinctly marketed and customized to the specific needs of a particular target audience; 
- highlighting both international and national best practices in subject matter;

- based on the authentic material and original texts and articles found in genuine Englishlanguage sources, but not translated from the native language of the student to prevent the misinterpretation or inconsistency of the terminology in focus;

- slowly obsolescent so that its educational life-cycle stays longer and the older texts or distant past realisms do not distort the present state of things in the subject;

- cognitive, informative and thought-provoking at the same time, enriching the student not only with its vocabulary, but also with professional knowledge;

- attention-grabbing, not boring or repetitive, offering diverse tasks to do while balancing the scientific and entertaining approaches as well as covering a good number of skills to practice;

- encouraging self-education, being a tool to provide motivation for further interest, research and development of the themes, thus challenging creative activity and creative thinking;

- learner-friendly, attractively designed and easy-to-use;

- adaptable for improvements and further enhancements as the human or electronic-nature factors might affect the final product in different ways, which could be necessary to correct in case some errors are made or new data have become available;

- offering a unique selling position, i.e. something that cannot be obtained or may be more difficult to obtain from other sources thus providing a unique educational proposition in the particular learner's area or field of studies;

- reasonably priced, offering a good value for money, which involves intentional cost-cutting at the stages of creation and publishing or production;

- competitive in comparison with other similar products;

- legally protected against possible piracy as being a registered product and not infringing the copyright of the applied sources.

All of the above fully applies to innovative products in teaching foreign languages, and in particular, foreign language of the profile, profession or the area of expertise, in other words, foreign language for specific and professional purposes.

\section{Conclusion}

Contemporary graduates are expected to demonstrate high flexibility, adaptability and international mobility. In the time of globalization and increasing internationalization of the workplace fluency in a foreign language becomes a must, undoubtedly increasing young professionals' employability and very often bringing a decisive competitive advantage. Consequently, training future specialists is unthinkable without the use of blended educational products on foreign language of their profile, profession or specialization, and teachers should be encouraged to demonstrate ingenuity and desire not only to extensively use the existing innovative products but also to create their own ones.

Therefore, for successful training, new educational standards demand new methods, approaches and more flexibility from both the student and the teacher. The task of providing high-quality education with fewer interactive teacher-group classes and more emphasis on self-study is inconceivable without innovative, preferably, e-learning material. Undertaking the project "Innovative product in Financial English" in the Plekhanov Russian University of Economics as an example of the general trend in higher education, we can conclude that in current conditions innovative educational products are in great demand since there are many uncovered gaps in study programs. Summing up, we believe that creating a copyright innovative product in ESPP requires bringing together teachers of foreign 
languages, administrative resource of the University and professional technical support, which is a feasible task we intend to work on.

\section{References}

Abrosimov, V. M. (1994). Pedagogicheskie innovatsii i tehnologii: Materiali II obl. nauch.-pract. konf [Pedagogical innovations and technologies]. Materials of the II regional scientific-practical conference held in Belgorod, Russia. Belgorod, Russia: BOIUU.

Artamonova, L. S. (2009). Organizatsionno-ekonomicheskoe razvitie obrazovatelnyh uslug v sfere vysshego obrazovaniya [Organizational-economic development of education service in higher education]. Moscow, Russia: Economic library. Retrieved from http://economylib.com/organizatsionno-ekonomicheskoe-razvitie-obrazovatelnyh-uslug-v-sfere-vysshegoobrazovaniya

Cambridge Financial English Blended Learning Course. (2013). Retrieved from $\mathrm{http} / / / \mathrm{www} . c a m b r i d g e e n g l i s h . o r g /$ exams-and-qualifications/financial/cambridge-financial-englishcourse

Delia, V. P. (2011). Pedagogicheskaya innovatika: innovatsionnoe obrazovanie, innovatsionnoe mishlenie, innovatsii [Pedagogical innovations: innovative education, innovative thinking, innovations]. Moscow, Russia: De-Po.

Diachenko, I. I. (1998). Pedagogicheskie novovvedenia v visshei shkole [Pedagogical innovation in higher education]. Krasnodar, Russia: KubGTU.

Drucker, P. (1985). Innovation and Entrepreneurship. New York, NY: Harper \& Row. PMCid:PMC1346743

European Higher Education Area. (2010). Bologna Process: History. Retrieved from the official Bologna Process website http://www.ehea.info/article-details.aspx?ArticleId=3

Helm, S. (2010). Market Leader Accounting and Finance. Edinburgh Gate, UK: Pearson Education Limited.

Innovation. (2013) In Business dictionary. Retrieved from http://www.businessdictionary.com/definition/innovation.html International Financial Reporting Standards. (2013). Retrieved from http://www.ifrs.org/IFRSs/Pages/IFRS.aspx

Investopedia. (2013). Retrieved from http://www.investopedia.com

Johnson, Ch. (2000). Market Leader Banking and Finance. Edinburgh Gate, UK: Pearson Education Limited.

Kolkova, M. (2007). Traditsii i innovatsii v metodike obuchenia inostrannim yazikam [Traditions and innovations in teaching foreign languages methodology]. Saint-Petersburg: Russia: KARO.

Korzhuev, A. V. (2003). Traditsii i innovatsii v visshem professionalnom obrazovanii [Traditions and innovations in higher vocational education]. Moscow, Russia: Moscow University. PMid:14608679 
Kuznetsova, O. V. (2012). Innovatzii v upravlenii katchestvom juriditcheskogo obrazovaniya Rossii [Innovations in law education quality management in Russia]. VIII International scientific-practical conference "Education and science of XXI century - 2012". Retrieved from http://www.rusnauka.com/29_NIOXXI_2012/Pedagogica/2_116338.doc.htm

MacKenzie, I. (2006). Professional English in Use: Finance. Cambridge, England: Cambridge University Press.

Ministry of education and science of Russian Federation. (2012). Federalnie gosudarstvennie standarti vishego professionalnogo obrazovaniya po napravleniyam podgotovki bakalavriata [Federal state education standards of higher professional education in bachelor's degree preparation]. Retrieved from the official site of the Ministry of education and science of Russian Federation http://xn-80abucjiibhv9a.xn-p1ai/\%D0\%B4\%D0\%BE\%D0\%BA\%D1\%83\%D0\%BC\%D0\%B5\%D0\%BD\%D1\%82\%D1\%8B/925

Naumov, A. A. (2013). Integrirovannoe i inklusivnoe obuchenie v obrazovatelnom uchrezhdenii. Innovatsionny opit [Integrated and inclusive education in educational establishment. Innovative experience]. Volgograd, Russia: Uchitel. PMCid:PMC3593029

Sergeeva, V. P. (2012). Innovatsii v obrazovatelnom protsesse [Innovations in Educational Process]. Moscow, Russia: UTS Perspectiva.

Turina, E. I. (1997). Pedagogicheskie innovatsii v neprerivnom obrazovanii. Tsentr. in-t povishenia kvalifikatsii rukovodyaschih rabotnikov i spetsialistov prof. obrazovania [Pedagogical innovations in continuing education. Central institute of managers and vocational education specialists' training]. Saint-Petersburg, Russia: B. I.

Zakon Rossiiskoi Federatzii “Ob obrazovanii” [Russian Federation law “About Education”]. (2010). Russian legislation. Moscow, Russia: Eksmo.

Zinkeviciene, N. (2004). How to examine educational organization absorptive capacity in the aspect of pedagogical innovations? Paper presented at the European Conference on Educational Research Post Graduate and New Researcher Pre-Conference, University of Crete, 20-21 September 2004. Retrieved from http://www.leeds.ac.uk/educol/documents/00003795.htm 